\title{
ZAGADNIENIE TEORII FILOZOFII PRZYRODY
}

\section{WPROWADZENIE}

Przekonywanie o fakcie ogromnego rozwoju nauk byłoby dziś niewątpliwie truizmem. Nawet nieprofesjonalista dostrzega przeobrażenia, jakim podlegają dyscypliny naukowe. Najbardziej rzucającą się w oczy cechą tych przeobrażeń zdaje się być różnicowanie się i wyodrębnianie nowych dziedzin badawczych, co ma miejsce w miarę narastania faktów, dostrzegania nowych aspektów, wypracowywania nowych metod itp. Powstają nowe dziedziny wiedzy, także na pograniczu już istniejących jako tzw. interdyscyplinarne $\mathrm{i}$ kompleksowe. Wszystkie one wydatnie zwiększają zakres poznawanej rzeczywistości. Może się nawet wydawać, że obejmą one swym zasięgiem całą rzeczywistość we wszystkich jej aspektach. Nie będzie więc białych plam niewiedzy w naszym poznawaniu świata i nas samych.

Nie sposób zaprzeczyć wyrażonemu przeświadczeniu, jeśli termin nauka będzie rozumiany szeroko przy włączeniu w jego zakres filozofii. Jeśli jednak ujmować naukę $\mathrm{w}$ sensie ściślejszym, a więc jako zespół dyscyplin szczegółowych, to nadal pozostanie wiele problemów nie objętych badaniem naukowym. Zagadnienia te bowiem mają specyficznie inny charakter, dotyczą płaszczyzny ontycznej i wobec tego nie dają się rozstrzygać przy pomocy metod nauk szczególowych. Co więcej, każda nauka staje się przedmiotem badań metanaukowych, a nadto inspiruje i rodzi problemy o charakterze czysto filozoficznym. Dziś przedstawiciele nauk, zwłaszcza fizycy i biolodzy, są świadomi pojawiania się na terenie nauk przyrodniczych problematyki filozoficznej. Rugowana z jednego miejsca pojawia się niemal automatycznie w innym. Filozofia więc jest nieunikniona. Odnosi się to w szczególności do filozofii przyrody.

Wiadomo, że istnieje wiele konkurujących ze sobą koncepcji filozofii przyrody. Toteż $\mathrm{w}$ naturalny sposób pojawia się pytanie, która $\mathrm{z}$ nich jest teorią najbardziej adekwatną względem rzeczywistości. Innymi słowy zapytujemy, mając w pamięci olbrzymie osiągnięcia współczesnych 
nauk, jak rozumiana filozofia przyrody może zadowolić dzisiejszego człowieka.

Zamierzeniem artykułu jest zaprezentowanie uzasadnionej odpowiedzi na to pytanie. W tym celu zreferujemy różne koncepcje filozofii przyrody ze szczególnym uwypukleniem teorii wypracowanej przez Profesora Kazimierza Kłósaka. Podamy także ilustracje współczesnych sposobów refleksji filozoficznej nad przyrodą dokonywanych poza nurtem tomistycznym. Wskażemy na kompatybilność tych ostatnich i koncepcji K. Kłósaka.

\section{PEWNE UWARUNKOWANIA WIELOSCI KONCEPCJI FILOZOFII PRZYRODY}

Rozważania nasze rozpoczniemy od przedstawienia kilku koncepcji filozofii przyrody z ukazaniem metodologicznych uwarunkowań ich odrębności.

\subsection{Różne sposoby pojmowania filozofii przyrody}

Wielowiekowe kontrowersje wokól istoty i zakresu wiedzy filozoficznej o przyrodzie nie doprowadziły dotąd do wykrystalizowania się jednej powszechnie przyjętej teorii; wręcz przeciwnie, powstało szereg koncepcji różniących się wyraźnie pojmowaniem statusu tak epistemologicznego, jak metodologicznego nauki określanej mianem filozofii przyrody. Niektórzy z filozofów nawet wprost negują możliwość i potrzebę istnienia i uprawiania takiego typu nauki. Pomijając te ostatnie zapatrywania przypomnijmy niektóre obiegowe sposoby pojmowania filozofii przyrody.

Jedna z koncepcji, nie mająca zresztą zbyt wielu zwolenników, pojmuje filozofię przyrody jako Wissenschaft am Anfang przypisując jej jedynie funkcję inspirowania (kiedyś - ujęcie historycystyczne, obecnie - ujęcie paralelistyczne) i wysuwania nowych problemów oraz hipotez, które znalazły lub znajdują potem rozwiązanie przy pomocy metod empirycznych. A więc tak rozumiana filozofia przyrody wysuwa jedynie odnośne sugestie przekazując je do rozstrzygnięcia naukom ${ }^{1}$. Tego rodzaju ujęcie przedmiotu i zadań tej nauki może być nazwane stanowiskiem minimalistycznym.

Szerzej rozpowszechniony jest pogląd, w myśl którego filozofia przyrody dokonuje uogólnienia wyników nauk przyrodniczych, tworząc przez to syntetyczny i bardziej jednolity obraz świata materialnego ${ }^{2}$. Taki syn-

1 Por. St. Mazierski, Elementy kosmologii filozoficznej i przyrodniczej, Poznań 1972, 35; A. G. van Melsen, Filozofia przyrody, Warszawa 1968, 10.

${ }^{2}$ Por. St. Mazierski, dz. cyt., 36; A. G. van Melsen, dz. cyt. 11-12. 
tetyczny pogląd na świat dając określoną całość bardziej spójną w porównaniu z sumą wyników jednostkowych, byłby zależny od stopnia rozwoju nauk w danym okresie i pozostawałby w płaszczyźnie empirycznej jako swoista nadbudowa nie dająca istotnie nowej wiedzy.

Inna koncepcja, związana $\mathrm{w}$ pewnej mierze $\mathrm{z}$ poglądami pozytywistycznymi, przyjmuje że filozofia przyrody to filozofia przyrodoznawstwa, a więc teoria nauk przyrodniczych mająca za przedmiot analizę i krytykę podstawowych założeń, pojęć i metod tych nauk. Nie dotyczy więc bezpośrednio samej rzeczywistości materialnej, lecz stanowi logikę, metodologię i epistemologię nauk przyrodniczych ${ }^{3}$. Innymi słowy dotyczy języka nauk przyrodniczych; może więc być nazwana metanauką. Doceniając wartość tego typu analiz, które same dla siebie konstytuują tzw. filozofię nauki, nadal nie mamy do czynienia $\mathrm{z}$ autonomicznym badaniem przyrody w płaszczyźnie filozoficznej.

W nurcie filozofii klasycznej dość powszechnie przyjmowany jest pogląd, zgodnie z którym filozofia przyrody jest filozoficznym badaniem przyrody. Tu punktem wyjścia jest istniejąca obiektywnie przyroda, nad którą dokonuje się refleksji filozoficznej. Za swój przedmiot bierze więc byt materialny jako materialny czy jako zmienny (ens mobile) badając jego naturę, różnorakie właściwości i przyczyny. To stanowisko chociaż uwzględnia podejście przedmiotowe i ontyczne, w czym wyodrębnia się od ujęcia tak empirycznego jak i metajęzykowego, znajduje różne formy realizacji. Właściwie mieści w sobie dwie wyodrębniające się koncepcje filozofii przyrody.

Jedna $\mathrm{z}$ nich zakłada, że skoro filozofia przyrody ma być dyscypliną filozoficzną, to $\mathrm{w}$ wyjaśnianiu natury i atrybutów materii winna stosować język, aparaturę pojęciową i metody filozofii bytu, gdyż ta ostatnia stanowi główny trzon całej filozofii. To jednak powoduje prawie automatycznie swego rodzaju ,podporządkowanie" filozofii przyrody metafizyce, tym samym uprawianie jej jako metafizyki szczegółowej lub stosowanej.

Możliwy jest jednak inny sposób uprawiania filozofii przyrody przy zachowaniu jej charakteru filozoficznego. Byłaby to próba „oddolnego" budowania filozofii przyrody w taki sposób, aby dane poznania potocznego i zwłaszcza naukowego poddać odpowiedniej „obróbce filozoficznej” i uzyskać na tej drodze zespół twierdzeń filozoficznych tłumaczących wewnętrzną strukturę bytów materialnych. Takie próby „oddolnego" uprawiania filozofii przyrody znalazły już realizację.

3 A. Stępień, Wstęp do filozofii, Lublin 19, 70. St. Mazierski, dz. cyt., 38-39. K. Kłósak, Pojęcie przedmiotu filozofii przyrody u autorów spoza nurtu neoscholastycznego, Rocz. Filoz. 14 (1966), z. 3, 19-20. 


\subsection{Ujęcia tomistyczne}

Rozbieżności poglądów odnośnie do przedmiotu i sposobu budowania filozofii przyrody mają $\mathrm{w}$ nurcie tomistycznym długie $\mathrm{i}$ wielorakie $u-$ warunkowania. Do głównych $\mathrm{z}$ nich zaliczyć trzeba pewne założenia, przyjmowane często milcząco, o' charakterze epistemologicznym i metodologicznym. Mamy tu "na myśli w pierwszym rzędzie fakt polegający na tym, że określony sposób pojmowania, a co za tym idzie, także uprawiania filozofii przyrody zdaje się być funkcją akceptowanej koncepcji samej nauki oraz przyjętej podstawy podziału nauk.

Wnikliwa analiza poglądów autorów tomistycznych w przedmiocie ujmowania i rozwiązywania problemów szczegółowych odnoszących się do filozoficznego tłumaczenia rzeczywistości materialnej potwierdza tezę, że wstępne założenia przyjęte przy konstrukcji przedmiotu filozofii przyrody (czy jakiejkolwiek innej nauki) rzutują na cały system, a zwłaszcza na sposób uzasadniania twierdzeń ${ }^{4}$. Wśród takich założeń decydującą rolę odgrywa właśnie różny sposób pojmowania tej nauki, jak i podstawy podziału nauk. W związku z tym pozostaje także różny sposób ujmowania stosunku nauk przyrodniczych do filozofii i odwrotnie.

\subsubsection{Koncepcje tradycyjne}

Koncepcje zaliczane do tej grupy określamy mianem tradycyjnych nie ze względów chronologicznych, lecz z uwagi na posługiwanie się $\mathrm{w}$ nich tradycyjnym pojęciem nauki i tegoż rodzaju podstawą klasyfikacji nauk. Autorzy zaliczani do tej grupy naukę pojmują jako ogólne i pewne poznanie dotyczące istoty rzeczy i wyjaśniające przez przyczyny. Za podstawę podziału nauk przyjmuje się trzy stopnie abstrakcji.

Pojawiają się tu trzy grupy poglądów na charakter filozofii przyrody. Jedna $z$ nich umieszcza ją na pierwszym stopniu abstrakcji wraz z naukami przyrodniczymi. Stanowisko takie zajmują m. in. J. Gredt, P. Hoenen, J. Hellin, J. Echarri, C. Boyer, F. Dougherty. Pociąga ono za sobą zrównanie filozofii przyrody z naukami przyrodniczymi. Żeby temu zapobiec przyjmuje się, że aspektem wyróżniającym dla filozofii przyrody jest uwzględnianie np. zmienności bytu lub tego o ile byt zmienny jest bytem. Inni tę różnicę upatrują w tym, że filozofia przyrody bada byt zmienny $w$ ostatecznych przyczynach, zaś nauki przyrodnicze - w przyczynach bliższych. Wszystkie tego typu próby usamodzielnienia filozofii przyrody okazują się niewystarczające z tych względów, że skoro tylko rozważamy byt zmienny jako byt, bądź w ostatecznych jego przyczynach, to już znajdujemy się na terenie metafizyki. Ma

4 St. Mazierski, Fizykalne a filozoficzne wyjaśnianie rzeczywistości, Rocz. Filoz. 7 (1959), z. $3,64-65$. 
tu miejsce jak gdyby „naturalna” niemożność usamodzielnienia filozofii przyrody, a więc odróżnienia jej zarówno od nauk przyrodniczych, jak i od metafizyki.

Inny pogląd tradycyjny, chcąc uniknąc wskazanych trudności, umieszcza filozofię przyrody pomiędzy pierwszym i drugim a trzecim stopniem abstrakcji i nazywa ją scientia media ${ }^{5}$. Zdaniem Ph. Selvaggiego filozofia przyrody od nauk przyrodniczych zapożycza materiał do badania (quasi materiale), do którego stosuje aparat pojęciowy metafizyki (quasi formale) ${ }^{6}$. Pogląd ten nie wydaje się zadawalający, ponieważ tożsamość przedmiotu formalnego i aparatury pojęciowej filozofii przyrody oraz metafizyki powoduje, że ta pierwsza jest częścią drugiej. Selvaggi tak rozumianą filozofię przyrody nazywa metafizyką stosowaną. Widzimy więc, że i ten pogląd nie gwarantuje autonomii filozofii przyrody w stosunku do metafizyki.

Trzeci z omawianych poglądów tradycyjnych wiąże filozofię przyrody z trzecim stopniem abstrakcji, a tym samym stawia znak równości między nią a metafizyką. Stanowisko takie zajmuje $\mathrm{m}$. in. A. G. van Melsen, według którego filozofia przyrody ma wspólny z metafizyką język i ten sam system pojęć. Przedmiotem filozofii przyrody jest struktura jednostkowo-gatunkowa materii analizowana przy pomocy pojęć metafizycznych. Jest więc metafizyką szczegółową zacieśnioną do bytu zmiennego. Zajmuje się właściwościami ogólnymi materii, podczas gdy nauki przyrodnicze określają właściwości specyficzne. Podobnie jak w poprzednich stanowiskach, tak i tutaj gubi się swoistość filozofii przyrody w relacji do metafizyki i nauk przyrodniczych. Dozwolone jest przechodzenie z języka naukowego do filozoficznego i odwrotnie.

\subsubsection{Koncepcje a utonomiczne}

Zaliczamy tu poglądy, które przyznają filozofii przyrody samodzielność w odniesieniu do metafizyki i nauk szczegółowych. Przyjmuje się w. nich współczesne rozumienie nauki jako logicznie spójnego zbioru twierdzeń uzyskanych i uzasadnionych metodycznie oraz nową podstawę podziału nauk, za jaką uważa się struktûrę logiczną danego systemu naukowego. Z tym wiąże się także akceptacja twierdzenia orzekającego, że pomiędzy naukowym i filozoficznym badaniem rzeczywistości zachodzi zasadnicza różnica.

Do inicjatorów tej koncepcji należy w pierwszym rzędzie J. Maritain. Określa on filozofię przyrody jako naukę, której przedmiotem jest byt zmienny, o íle jest poznawalny intelektualnie od strony swej isto-

5 St. Mazierski, Czy filozofia przyrody inspiracji arystotelesowsko-tomistycznej jest tzw. naukq pośredniq?, Rocz. Filoz. 14 (1966), z. 3, 5-16.

6 Tamże, 8-11; Ph. Selvaggi, Cosmologia, Romae 1959, 6-11; tenże, Fisica, cosmologia, metafisica, w: Studi filosofici.... 200. 
ty ${ }^{7}$. To poznawanie intelektualne bytu zmiennego $\mathrm{w}$ jego istocie nazywa czasem rozpatrywaniem w świetle ontologicznym w odróżnieniu od ujmowania go w naukach przyrodniczych w świetle empiriologicznym (w zależności od sposobu definiowania na podstawie obserwacji zmysłowej). Te analizy ontologiczne rozumie inaczej niż w metafizyce, w znaczeniu szerszym, przez co filozofia przyrody uzyskuje autonomię w stosunku do metafizyki ${ }^{8}$.

Nie wdając się w szczegółowe oceny wypracowanej przez J. Maritaina teorii filozofii przyrody należy ogólnie stwierdzić, że nie jest ona wolna od pewnych mankamentów, do których można zaliczyć nie zawsze precyzyjne sformułowania, często antropomorficzne, mało zadowalające próby uwspółcześnienia dawnych określeń i rozróżnień terminologicznych; nie uwolnił się także do końca od tradycyjnej zasady podziału nauk uważając nauki przyrodnicze i filozofię przyrody za dwa różne gatunki epistemologiczne $\mathrm{w}$ obrębie tego samego rodzaju abstrakcji ${ }^{9}$. Mimo tych i podobnych braków prace Maritaina we wskazanym zakresie trzeba uznać za oryginalną i inspirującą teoretycznie próbę wypracowania koncepcji filozofii przyrody jako samodzielnej nauki filozoficznej.

To schematyczne przedstawienie różnorakich ujęć filozofii przyrody pozwala na ogólne zorientowanie się w aktualnej sytuacji odnośnie do racji bycia i uprawiania tej kontrowersyjnej dyscypliny. Jeżeli ma ona stanowić odrębną dziedzinę badań filozoficznych, to należy precyzyjnie określić jej przedmiot, metodę i zadania. Realizacji tego celu podjął się Profesor Kazimierz Kłósak poświęcając mu szereg doniosłych rozpraw.

3. ODDOLNA PRÓBA UPRAWIANIA FILOZOFICZNEGO POZNANIA PRZYRODY

W ponad czterdziestoletniej działalności badawczej ks. Kazimierza Kłósaka główne miejsce zajmują dociekania odnoszące się do wypracowania spójnej, zwartej koncepcji filozofii przyrody jako samodzielnej dyscypliny filozoficznej. W skład tej koncepcji wchodzą zarówno zagadnienia tyczące się teorii, jak i metodologii filozofii przyrody. W tym artykule zwróci się uwagę jedynie na pierwsze $\mathrm{z}$ wymienionych zagadnień.

7 J. Maritain, La philosophie de la nature, Paris 1935, 132.

$8 \mathrm{~K}$. Kłósak, Maritainowe próby wyodrębnienia filozofii przyrody metafizyki $i$ nauk przyrodniczych, Rocz. Filoz. 12 (1964), z. 3, 17-29; por, jego $Z$ teorii $i$ metodologii filozofii przyrody, Poznań 1980, 87-89.

${ }^{9} \mathrm{~K}$. Kłósak, $Z$ teorii $i$ metodologii filozofii przyrody, 93. Od wielu lat Kłósak zajmuje się oceną prac J. Maritaina w odniesieniu do przedmiotu filozofii przyrody, jak też i opinii innych tomistów o tych poglądach. Por. dane bibliograficzne w cyt. pracy. 


\subsection{Podstawy koncepcji}

Analiza stanowisk zajmowanych przez różnych tomistów, a zwłaszcza J. Maritaina, D. Nysa, J. Lemaire'a, F. Renoirte'a, P. Hoenena, Ph. Selvaggiego, M. Krąpca, St. Kamińskiego, J. Kalinowskiego i wielu innych, doprowadziła K. Kłósaka do wypracowania własnej koncepcji filozofii przyrody, u podstaw której przyjęto szereg założeń metateoretycznych i teoretycznych. Wskażemy na najważniejsze $\mathrm{z}$ nich.

a) Chcąc określić miejsce filozofii przyrody wśród innych nauk odrzuca tradycyjną podstawę podziału nauk, przyjmując w jej miejsce odrębność punktu widzenia (przedmiot formalny) i sposobu definiowania.

b) $\mathrm{Z}$ dwu istniejących teorii nauk przyrodniczych, ontologizującej i empiriologicznej, opowiada się za tą ostatnią. Według tego ujęcia nauki zajmują się zjawiskami i ich powiązaniami, a więc są zrelatywizowane do tego co podlega obserwacji i pomiarowi i co może być weryfikowane przez doświadczenie ${ }^{10}$. Nauki te nie zawierają żadnych twierdzeń filozoficznych (jak w koncepcjach ontologizujących) i z takowych nie wynikają oraz do żadnych wniosków filozoficznych bezpośrednio nie prowadzą. Można jednak mówić o wyodrębnianiu implikacji filozoficznych typu redukcyjnego, a więc takich, które nie odnoszą się już do porządku empiriologicznego, ale tylko pod warunkiem, że stanowią one koniunkcję funkcji nauk szczegółowych i podzielanej wizji filozoficznej ${ }^{11}$.

c) Gdy idzie o teorię bytu, to odcina się od konkretystyczhtej teorii rozwijając, w nawiązaniu do jednego z rozumień metafizyki u Maritaina, abstrakcjonistyczne i ogólne ujęcie bytowości. Ujmuje ona podstawowy dla wszystkich przedmiotów ,aspekt bycia czymś istniejącym realnie w ogólności" ${ }^{12}$, który odnosi się zarówno do bytu jako bytu, jak też do różnych typów bytu i specyficznych sposobów istnienia ${ }^{13}$. Do tych ostatnich włącza - uznając wielość sposobów istnienia - także istnienie przedmiotów czysto intencjonalnych, przypisując im obiektywność, nie zaś realność.

d) Poza swoistą koncepcją metafizyki oraz przyjęciem empiriologicznego rozumienia nauk szczegółowych opowiada się za możliwością filozoficznego poznania przyrody. Nie negując prawomocności i wartości poznania $w$ ramach nauk przyrodniczych dostrzega ich niewystarczalność w tym znaczeniu, iż nie mogą one odpowiedzieć na wszystkie pytania odnoszące się do przyrody. Istnieje bowiem szereg zagadnień, których nauki przyrodnicze nie mogą ani podejmować, ani rozwiązywać z

10 Tamże, $14-22$.

11 Tamże, 39-40; por. jego: Nauki przyrodnicze a filozofia, Analecta Cracoviensia 8 (1976), 36-58.

${ }_{12} \mathrm{~K}$. Klósak, $Z$ teorii $i$ metodologii filozofii przyrody, 51 ; por. $Z$ zagadnień filozoficznego poznania Boga, Kraków 1979, t. I, 85-87.

${ }^{13} \mathrm{Z}$ zagadnień filozoficznego poznania Boga, 85. 
racji przyjętych metod badawczych decydujących o fragmentaryczności i empiryczności poznania. Te zagadnienia mogą i powinny stać się przedmiotem badania filozoficznego. K. Kłósak ${ }^{14}$ dzieli je na trzy grupy. Pierwsza $\mathrm{z}$ nich zawiera ogólne problemy związane $\mathrm{z}$ określeniem i wyodrębnieniem typu bytu z obrębu przyrody, druga - problemy dotyczące istoty bytu (spartykularyzowanego) i jego przypadłości ilościowo-jakościowych oraz przyczyn, trzecia - zagadnienia odnoszące się do podstawowej struktury wskazanego typu bytu, która by stanowiła tłumaczenie ogólnoempirycznych twierdzeń o przyrodzie. Te i tym podobne problemy mogą stać się przedmiotem badania osobnej dziedziny, którą nazywamy filozofią przyrody.

\subsection{Określenie przedmiotu filozofii przyrody}

Przytoczone skrótowo założenia metateoretyczne i teoretyczne przyjęte przez naszego Filozofa, jak też przeprowadzona przezeń dogłębna analiza krytyczna tak dotychczasowych koncepcji wypracowanych w ramach tradycji tomistycznej, jak i ujęć spoza jej nurtu, doprowadziły go do wypracowania własnego poglądu na przedmiot filozofii przyrody.

Jest nim ,typ bytu charakterystyczny dla przyrody lub - inaczej się wyrażając - byt realny zacieśniony do określeń, jakie są właściwe dla wszystkiego, co jest częścią przyrody. Moglibyśmy także powiedzieć w perspektywie egzystencjalistycznej, że przedmiotem badań filozofii przyrody jest aspekt bycia czymś istniejącym realnie w ramach przysługującego przyrodzie typu bytu" ${ }^{15}$.

Mówiąc, że „filozofia przyrody jest nauką o aspekcie istnienia realnie jako ten typ przedmiotów, który składa się na przyrodę" ${ }^{16}$ podkreśla K. Kłósak fakt, iż chociaż ta nauka koncentruje się na wyjaśnianiu strony istotowej bytów materialnych, to jednak nie pomija ich realnego istnienia. Sposób istnienia bytów materialnych jest tak charakterystyczny, że może służyć do ich określania. Sugeruje, że w miejsce tradycyjnie przyjmowanego ruchu jako istotnej cechy materii można przyjąć jej istnienie w czasie, które wydaje się być głębszą i bardziej podstawową od ruchu cechą rzeczywistości materialnej. Uwzględnianie czasowego sposobu istnienia bytów zmiennych ${ }^{17}$, a więc istnienia niejako rozkładającego się sukcesywnie w czasie, podsuwa Kłósakowi myśl o ewolucjonistycznym (a zatem i dynamicznym, i procesualnym) pojmowaniu materii.

$14 \mathrm{Z}$ teorii $i$ metodologii filozofii przyrody, 46-48.

15 Tamże, 105.

16 Tamże, 106.

17 Tamże, 49, 106; por. Słowo wstępne, w: Z zagadnień filozofii przyrodoznawstwa filozofii przyrody, pod red. K. Kłósaka, Warszawa 1976, t. 1, 8-9. 
Z dotychczasowych uwag widoczna jest odrębność filozofii przyrody od nauk przyrodniczych i metafizyki. Nauki przyrodnicze ograniczone przez swe metody do ujmowania aspektów zjawiskowo-mierzalnych nie podejmują pytania o ostateczną strukturę rzeczywistości materialnej. Metafizyka zaś zainteresowana jest w badaniu aspektów ogólnobytowych. Konsekwentnie wymienione dyscypliny pozostawiają miejsce dla filozoficznego badania przyrody. To ostatnie, jako przedmiotowe, różni się z kolei od filozofii przyrodoznawstwa, która jest metodologią, gnoseologią i filozofią nauk przyrodniczych, nie zaś filozoficznym dociekaniem nad samą przyrodą. Tym samym można mówić o filozofii przyrody jako o autonomicznej dyscyplinie filozoficznej.

\section{WSPÓECZESNE SPOSOBY REFLEKSJI FILOZOFICZNEJ}

Podamy tu przykłady rozważań filozoficznych odnoszących się $\mathrm{w}$ zamierzeniu do przyrody, a które nie mieszczą się wprost w zreformowanych sposobach pojmowania filozofii przyrody, także tomistycznych. Najbliższe wydają się być dociekaniom z zakresu filozofii przyrodoznawstwa, zwłaszcza tej jej części, która analizuje podstawowe założenia i najogólniejsze rezultaty nauk przyrodniczych. Nie mogą być jednak z nimi utożsamione.

Ilustracje te będą dowolnie wybranymi przykładami filozofowania $i$ to o charakterze możliwie neutralistycznym, tzn. nie angażującymi wprost konkretnego systemu filozoficznego. Tego rodzaju sposób filozofowania zdaje się być współcześnie coraz bardziej powszechny.

\subsection{Przykład filozoficznych rozważań nad czasem}

Podamy tu dwie ilustracje odnoszące się do koncepcji czasu, z których jedna została sformułowana przez Z. Augustynka, druga zaś przez C. West Churchmana.

a) Z. Augustynek podaje relacyjno-obiektywistyczną koncepcję czasu. Ograniczymy się do zreferowania założeń teorii przeszłości, teraźniejszości i przyszłości jako pojęć pomocniczych dla skonstruowania koncepcji czasu ${ }^{18}$. Teoria ta jest oparta na pięciu następujących założeniach.

1. Przyjmuje się ontologię mnogościową. Znaczy to, że zakłada się istnienie indywiduów, ich zbiorów, zbiorów zbiorów itd.

2. Przyjmuje się ontologię ewentyzmu. Inaczej mówiąc zakłada się, że a) jedynymi indywiduami są zdarzenia fizyczne, b) rzeczy (ciała) są

18 Z. Augustynek, Przeszłość, teraźniejszość, przyszłość, Studium filozoficzne, Warszawa 1979, zwłaszcza str. 13-25. Por. tegoż Natura czasu, Warszawa 1975, Własności czasu, Warszawa 1970. 
zbiorami zdarzeń fizycznych, c) w zbiorze zdarzeń fizycznych zachodzą różne relacje czasowe, przestrzenne, czasoprzestrzenne oraz fizyczne.

Konsekwencją podanych dwu założeń (tj. 1. i 2) jest uznanie „warstwowej" struktury rzeczywistości. Kolejnymi warstwami są: indywidua (typ 0), zbiór indywiduów (typ 1), zbiór zbiorów indywiduów (typ 2) itd. Każda warstwa następna jest zbiorem podzbiorów warstwy poprzedniej. Przechodzenie do warstw wyższych jest połączone ze wzrostem stopnia abstrakcji.

3. Teoria przeszłości, teraźniejszości i przyszłości jest formułowana w oparciu o szczególną teorię względności.

4. Przeszłość, teraźniejszość i przyszłość definiuje się przy pomocy relacji czasowych: wcześniej, równocześnie, później.

5. Zakłada się, że przeszłość i przyszłość różnią się między sobą fizycznie.

Wychodząc z tych założeń Augustynek konstruuje trzy wersje teorii przeszłości, teraźniejszości i przyszłości: dwie zdarzeniowe (jedną względną i jedną absolutną) oraz jedną „momentową" względną. Wewnątrz obydwu wersji zdarzeniowych można zdefiniować przeszłość, teraźniejszość i przyszłość rzeczy (ciał). A zatem bardziej pierwotne są pojęcia przeszłości, teraźniejszości oraz przyszłości zdarzeń. Wtórnymi zaś analogiczne pojęcia w odniesieniu do rzeczy (ciał).

b) Rozważmy cztery następujące postulaty odnoszące się do możliwości poznania i oceny przeszłości oraz przyszłości:

A. Poznanie przeszłości jest możliwe. Postulat ten utrzymuje, że „,jest rzeczą możliwą opisanie tego, co zdarzyło się w przeszłości i czynności tej przypisuje się większą lub mniejszą efektywność" ${ }^{19}$.

B. Poznanie przyszłości jest możliwe.

C. Ocena przeszłości może być dokonana niezależnie od oceny przyszłości. Znaczy to, że „czynność polegająca na ocenie tego, co zdarzyło się w przeszłości, daje się rozdzielić od czynności polegającej na ocenie tego, co zdarzy się w przyszłości" ${ }^{20}$.

D. Ocena przyszłości może być dokonana niezależnie od oceny przeszłości.

Biorąc pod uwagę treść powyższych postulatów oraz ich negacje (oznaczane symbolami: $-\mathrm{A},-\mathrm{B},-\mathrm{C},-\mathrm{D}$ ) otrzymuje się 7 stanowisk tyczących się poznania i oceny przeszłości wraz z przyszłością ${ }^{21}$.

${ }_{19}$ C. West Churchman, Epilog. Prognozowanie przyszłości na podstawie przeszłości, ocena trendów przez teorię systemów, w: Ogólna teoria systemów, Tendencje rozwojowe, pod red. G. J. Klira, Warszawa 1976, 418.

20 Tamże, 1. c.

${ }^{21} \mathrm{Z}$ logicznego punktu widzenia możliwych jest 16 przypadków. Wspomnianych 7 przypadków autor podaje na str. 419. 
Są one następujące:

A, B, C, D: „Przeszłość i przyszłość można rozdzielićc”

A, B, C, -D: „Prognozowanie na podstawie przeszłości”

$\mathrm{A}, \mathrm{B},-\mathrm{C}, \mathrm{D}$ : „Ocena przeszłości na podstawie przyszłości”

$\mathrm{A},-\mathrm{B}, \mathrm{C},-\mathrm{D}$ : „Ocena przeszłości, ale nie przyszłości”

- A, B, - C, D: „Ocena przyszłości, ale nie przeszłości”

$\mathrm{A}, \mathrm{B},-\mathrm{C},-\mathrm{D}$ : „Integracja przeszłości z przyszłością"

$-\mathrm{A},-\mathrm{B},-\mathrm{C},-\mathrm{D}$ : ,Sceptycyzm".

Churchman opowiada się za stanowiskiem zwanym ,integracją przeszłości z przyszłością". Postawie tej, mającej wiele odcieni znaczeniowych, można nadać znaczenie najmocniejsze. Dla uzasadnienia przedstawionego stanowiska autor bierze pod uwagę wyniki z zakresu badań operacyjnych.

Zgadzając się, że jest to pogląd dyskusyjny, sygnalizujemy jedynie jego istnienie. Tego rodzaju pogląd nie mieści się w żadnej z nauk szczegółowych, należy do dziedziny badań filozoficznych, szeroko pojętych. Unaocznia fakt, że przeszłość świata, rzeczy, zdarzeń - podobnie jak przyszłość - jest głęboko ukryta, a jej badanie złożone, trudne i nacechowane niepewnością.

\subsection{Przykład ontologii systemowej}

Ogólna teoria systemów i różne koncepcje systemowe, choć nie zajmują się wprost zagadnieniami filozoficznymi, inspirują jednak swoistą postawę filozoficzną. Sam Bertalanffy mówi o filozofii systemów, o ontologii i epistemologii systemów mając na uwadze to, że rzeczywistość stanowi jeden wielki system lub zbiór systemów, hierarchię całości zorganizowanych z różnorakich części oddziaływających wzajemnie na siebie. Dostrzeżenie w świecie realnie istniejącym owej złożoności, całościowości, hierarchicznego uporządkowania oraz wybór proporcjonalnej do tych jakości systemowych aparatury badawczej określa istotę tej nowej orientacji myślowej. Nie tylko rzeczywistość fizyczna, ale także świat wartości, symboli, czy kultury jest czymś w pełni realnym ${ }^{22}$. Wszelkie obiekty jako systemy bądź rzeczywiste, bądź pojęciowe, czy abstrakeyjne, jeśli nawet nie są dane wprost we wrażeniach, wykazują swą „rzeczywistość” ${ }^{23}$. Ogólna teoria systemów jest „modelem pewnych ogólnych aspektów świata rzeczywistego. Stanowi również sposób dostrzegania rzeczy, które przedtem pozostawały poza polem widzenia

22 L. von Bertalanffy, General System Theory, Foundations, Development, Application, Harmondsworth $1973, \cdot$ XXI.

${ }^{23}$ L. von Bertalanffy, Historia rozwoju $i$ status ogólnej teorii systemów, w: Ogólna teoria systemów. Tendencje rozwojowe, 43.

7 - Analecta Cracoviensia 
lub były pomijane i w tym znaczeniu jest kierunkiem metodologicznym. Podobnie jak każda teoria naukowa o szerokim zasięgu ma związek z odwiecznymi problemami filozofii, na które próbuje dać odpowiedź" ${ }^{24}$. Bertalanffy nie ogranicza filozofii naukowej do logiki, semantyki, metajęzyka nauki, lecz analizuje szereg kategorii naukowych i filozoficznych celem stworzenia podwalin pod realistyczną wizję świata i obiektywistyczną koncepcję doświadczenia ${ }^{25}$. Ta wizja świata jest na wskroś dynamiczna, umożliwia ujęcie rzeczywistości jako „dynamicznej organizacji procesów" ${ }^{26}$, ustawicznego stawania się. Ogólna teoria systemów zdaje się być uniwersalnym narzędziem intelektualnym dla pojęciowego i formalnego opisu podstawowych własności rzeczywistości i jako taka może konkurować z filozofią klasyczną, inspirować do nowych rozwiązań ontologicznych ${ }^{27}$.

Sformułowane przez Bertalanffy'ego sugestie i myśli, nie opracowane szerzej, podejmuje E. Laszlo ${ }^{28}$. Utrzymuje, że ogólne spojrzenie na wyniki badań naukowych prowadzi do utworzenia systemowego obrazu przyrody i człowieka jako określonych całości. Stwierdza, że ujęcie systemowe pojawia się wszędzie, ponieważ całości zorganizowane nauka wykrywa obecnie w najrozmaitszych dziedzinach, badawczych ${ }^{29}$. Nowe spojrzenie na naturę rzeczywistości i odpowiedni sposób jej badania wyrasta wyraźnie z załamania się mechanistyczno-pozytywistycznego ideału nauki. Stopniowo toruje sobie drogę syntetyczno-całościowy sposób patrzenia na rzeczy i zjawiska, co implikuje nowy filozoficzny pogląd na rzeczywistość, określany systemowym sposobem interpretacji świata, lub -krócej ,,systemowym obrazem świata".

Zajmując się systemami naturalnymi (są nimi m. in. atomy, komórki, narządy, organizmy, społeczności, biosfera), Laszlo przypisuje każdemu z tych systemów pewne nieprzemijające właściwości, tzw. inwarianty organizacji. Oto najważniejsze $\mathrm{z}$ nich: a) systemy naturalne stanowią całości o nieredukalnych właściwościach, b) podtrzymują swe istnienie $\mathrm{w}$ zmieniającym się otoczeniu, c) autokreują się w odpowiedzi na wyznanie otoczenia (postępujące przekształcanie i wzrost zintegrowania kolejnych poziomów organizacji), d) systemy naturalne pełnią rolę dwukierunkowych łączników w świecie przyrody (wiążą składniki

24 Tamże, 44.

25 J. Kamaryt, From Science to Metascience and Philosophy, w: Unity through Diversity. A Festschrift for L. von Bertalanffy, ed. by W. Gray and N. Rizzo, New York 1973, v. I, 76.

${ }_{26}$ Tamże, 80.

27 A. Locker, On the Ontological Foundations of the Theory of Systems, w: Unity through Diversity, 537-539.

${ }_{28}$ E. Laszlo, Systemowy obraz świata, tłum. U. Niklas, Warszawa 1978. Tenże: Introduction to System Philosophy, New York 1972.

29 E. Laszlo, Systemowy obraz świata, 38. 
systemu - z niższego szczebla - z systemem nadrzędnym, któremu podlega). To ustrukturalizowanie hierarchiczne jest warunkiem przetrwania systemów naturalnych, które są tworami dynamicznymi, zdolnymi do przystosowania się. Systemy w przyrodzie lączą się, tworzą supersystemy pozostające $w$ harmonijnej równowadze dynamicznej ${ }^{30}$.

W koncepcji systemowej człowieka pojmuje się jako jeden z rodzajów systemów, należących do złożonej hierarchii przyrody, który na drodze rozwoju uzyskał zdolność refleksji, poznawania świata i siebie, tworzenia kultury i wartości. Systemowy obraz człowieka jest na wskroś realistyczny i humanistyczny, ujawnia jego twórcze uzdolnienia i perspektywy rozwojowe.

\section{ODNIESIENIE DO KONCEPCJI AUTONOMICZNEJ}

Sposób stawiania i roztrząsania zagadnień, podjętych w przytoczonych przykładach, wykazuje pewne cechy swoiste, które nie pozwalają zaliczyć go ani do zakresu nauk przyrodniczych, ani też w obręb zastanych sposobów filozofowania (klasycznego, fenomenologicznego, analitycznego itp.). Nauki szczegółowe bowiem ujmują te problemy od strony zjawiskowej (i na niej w zasadzie poprzestają), przy użyciu metod obserwacji, opisu i wyjaśniania oraz weryfikacji o charakterze wyraźnie empirycznym. Wskazany w ilustracjach sposób filozofowania nie jest ani analizą języka nauki, czy metod jej uprawiania, ani też zastosowaniem metafizycznej wizji świata czy ontologicznych zabiegów poznawczych do tłumaczenia np. natury czasu, pojmowania przyrody i człowieka. Mimo wielości i różnorodności tych sposobów wszystkie one ujawniają pewne podobieństwo i wspólne rysy. Polega to na nawiązywaniu, wykorzystywaniu czy wprost oparciu się na naukach szczegółowych, bez zamykania się jednak w ich empiryczności. Nie mamy tu bowiem do czynienia $z$ uogólnianiem twierdzeń empirycznych pochodzących $\mathrm{z}$ różnych nauk, ale raczej ze swoistym zakotwiczaniem refleksji filozoficznej w naukach przyrodniczych. Wychodząc poza te nauki filozofia tego typu nastawiona jest na dociekania przedmiotowe o charakterze ontologicznym, na ujęcie istoty podstawowych właściwości struktur i procesów. Nie oznacza to z kolei jakiegokolwiek odgórnego czy apriorycznego budowania filozofii, ani też dominacji metafizyki nad naukami szczegółowymi.

Charakteryzowany przez nas styl współczesnego filozofowania odznacza się nadto pewną otwartością ,ontologiczną". Mamy tu na myśli to, że w początkowej fazie tego tworzenia przeważa aspekt fenomeno-

30 Tamże, 96. 
logiczny, który stopniowo jest „dopełniany” przez wnikanie w istote badanych przedmiotów. $\mathrm{Z}$ reguły proces ten nie podlega zakończeriu postaci utworzenia gotowego, globalnego systemu; przeciwnie, jest otwarty na dalsze konstruowanie bardziej adekwatnych przybliż do rzeczywistości ${ }^{31}$.

Uwyraźnijmy dotychczasowe rozważania. W odniesieniu do zachodzących między naukami przyrodniczymi a ontologią przyjzlo sį wyróżniać trzy odmienne stanowiska, które K. Zamiara ${ }^{32}$ nazywa: empirystycznym (twierdzenia ontologiczne są uogólnieniami twierdzeń empirycznych), apriorystycznym (ontologia jest tu ,,z góry” zakładana i stosowana do nauk szczegółowych) i kompromisowym (założenia ontologiczne są uwikłane w kontekście teorii empirycznych). W tym ostatnim stanowisku wyróżnia się dwa warianty: a) konwencjonalistyczny (założenia ontologiczne są umownym składnikiem teorii i nie podlegają weryfikacji empirycznej), b) kontekstowo-empiryczny (tezy ontologiczne sprawdza się w doświadczeniu wraz z całym kontekstem teoretycznym); wariant ten może przybierać różne odcienie w zależności od rozumienia procedury sprawdzania ${ }^{33}$.

Jeśli posłużyć się podaną klasyfikacją, to omówione przez nas ilustracje, określające pewien specyficzny styl filozofowania, umownie nazywany tu współczesnym, trzeba zaliczyć do stanowiska trzeciego. Jednakże nie stanowi jego wariantu ani pierwszego, ani drugiego, raczej swoistą modyfikację obydwu, względnie różne od nich ujęcie.

Propozycja ks. K. Kłósaka, będąca próbą autonomicznego uprawiania filozofii przyrody podobnie winna być zaliczona do stanowiska trzeciego. Wyraźnie jednak widać, że ani wariant a), ani wariant b) nie wyczerpują zawartości tej koncepcji. Innymi słowy nie daje się ona zamknąć nie tylko w każdym pojedynczym wariancie, ale także w ich sumie; jest zdecydowanie nowym, oryginalnym wariantem, w myśl którego tezy ontologiczne nie są ani prostymi konwencjami, ani elementami kontekstowymi teorii sprawdzalnymi empirycznie, lecz implikacjami ontologicznymi o charakterze redukcyjnym.

Analizy porównawcze współczesnego stylu filozofowania i reprezentowanego przez Profesora K. Kłósaka byłyby zwykłym nieporozumie-

${ }^{31}$ Pojęcie otwartości, którym tu operujemy, nie jest identyczne $\mathrm{z}$ takimże pojęciem odnoszonym do filozofii Tomaszowej. W naszym przypadku chodzi o otwartość na ujęcie ontologiczne, choćby w szerokim rozumieniu, tam zaś - na otwartość względem nauk przyrodniczych i ewentualnie na dopełnienia logiczno-metodologiczne. Por. St. Mazierski, Elementy kosmologii filozoficznej i przyrodniczej, 6978; tenże: Czy filozofia św. Tomasza z Akwinu jest systemem zamkniętym?, Rocz. Filoz. 16 (1968), z. 3, 25-35.

${ }^{32} \mathrm{~W}$ sprawie statusu pojęć ontologicznych i postępu, w: Założenie teoretyczne badań nad rozwojem historycznym, pod red. J. Kmity, Warszawa 1977, 47-48.

${ }^{33}$ Tamże. 
niem bez wskazania odmienności płaszczyzn, na których przebiegają dociekania. W przypadku pierwszym są to rozważania przedmiotowe, w drugim - dokonują się przede wszystkim w metapłaszczyźnie. Tu proponuje się pewien styl uprawiania filozofii przyrody zakotwiczony $\mathrm{w}$ naukach przyrodniczych określając ścisłe jego ramy. Dzięki temu otrzymuje się zwartą teorię, nie zaś zlepek luźnych wskazań i reguł filozofowania nad przyrodą. W teorii tej szczególny sposób zabiega się o ukazanie jej specyficzności, a więc różnicy w odniesieniu do nauk przyrodniczych i metafizyki, uzyskując autonomiczność jej ujęcia. Od strony logicznej teoria Kłósaka charakteryzuje się wysoką precyzją i ścisłością konstrukcji. Analizy są niezwykle wnikliwe, wnioski wynikają z uwzględniania krytycznej oceny istniejących poglądów. Można zatem powiedzieć, że mamy tu do czynienia $\mathrm{z}$ tworzeniem teorii uprawiania filozofii przyrody, natomiast $\mathrm{w}$ przypadku rozważań przedmiotowych $\mathrm{u}$ innych filozofów dokonywana jest konkretna „robota filozoficzna”, z której dopiero można odczytywać, $i$ to nie bez trudu, założoną (nie zawsze świadomie) teorię.

Uznaje się, że poznanie naukowe ma większą zawartość informatywną, precyzję i stopień pewności $\mathrm{w}$ porównaniu $\mathrm{z}$ poznaniem zdroworozsądkowym. Nic więc dziwnego, że zarówno propozycja K. Kłósaka, jak też współczesne style filozofowania są zakotwiczone w naukach przyrodniczych, aczkolwiek nie w identyczny sposób. Obydwa stanowiska są więc otwarte na nauki przyrodnicze. Pod tym względem, przynajmniej we wstępnych etapach filozofowania, harmonizują one ze sobą.

Nie można jednak nie podkreślić faktu większej „,pełności filozoficznej" koncepcji Profesora w stosunku do zawartej, przynajmniej implicite, we współczesnych stylach filozofowania. W ujęciu Z. Augustynka, C. W. Churchmana, czy ogólnie systemowych, odczuwa się pewien niedosyt; brak elementu specyficznie ontologicznego. Chociaż ujęcia te są logicznie poprawne, to jednak zdają się gubić istotę rozważań z zakresu filozofii przyrody. Koncepcja K. Kłósaka zawiera w sobie istotne elementy pozwalające konstruować teorię, która by dała adekwatne wyjaśnienie rzeczywistości materialnej. Teoria ta może być uważana za pewnego rodzaju „dopełnienie" współczesnych stylów filozofowania, o ile tylko te ostatnie nie są formułowane jako kompletne i wykluczające ujęcia alternatywne.

Dla ks. prof. K. Kłósaka filozofia w ogóle, a filozofia przyrody w szczególności, była i jest głównym zadaniem życia. Jej uprawianiu nadal poświęca swe wysiłki niemal całkowicie. Wytrwałe i konsekwentne zmierzanie do prawdy, wymagające - zawsze, a zwłaszcza w tej dziedzinie - wysokiej dyscypliny i ogromnej rzetelności w myśleniu, wielkiej pracowitości, ścisłości analiz, rozumowań, stałej samokontroli for- 
mułowanych twierdzeń, zaowocowało opublikowaniem szeregu poważnych monografii i rozpraw, w których zostały podjęte i rozwiązane, lub przynajmniej przedyskutowane liczne problemy zarówno merytoryczne, jak przede wszystkim metaprzedmiotowe. Te ostatnie znalazły swój zewnętrzny wyraz $w$ pracy pt. $Z$ teorii $i$ metodologii filozofii przyrody, która pozostanie oryginalnym i trwałym wkładem w rozwój tomistycznej filozofii przyrody i myśli filozoficznej w ogóle.

\section{A THEORY OF PHILOSOPHY OF NATURE}

\section{Summary}

The authors attempt a characteristic of K. Klósak's work on philosophy of nature against the background of comparative analysis of various concepts of philosophy of nature. They seek for the theory which ist most adequate to reality and will best satisfy contemporary man.

The multiplicity of concepts of philosophy of nature is methodologically conditioned by acceptance of certain preliminary assumptions which effect the whole system of theorems and the way in which they are substanciated. Among these theorems, the decisive role is played by different ways of understanding science and rules of classifying sciences. Hence, we classify the very concepts of philosophy of nature into traditional and autonomous ones depending on the acceptance of the old or the modern theory of science and rules of classification of sciences. The traditional concepts of philosophy of nature, e.g. those of J. Gredt, P. Hoenen, F. Dougherty, Ph. Selvaggi, A. Melsen, have not really succeeded in assessing its relation to natural sciences and to metaphysics. Autonomous concepts, e. g. those of Maritain or $\mathrm{K}$. Kłósak are attempts of fundamental practice of philosophical cognition of science and thus ascertaining for it a methodological status or field of studies at least comparatively autonomous.

The authors have characterised Kłósak's theoretical assumptions and metatheoretical concepts and assessed his definition of the subject matter of philosophy of nature as "a science concerning the aspect of existence in reality as the type of subjects which constitute nature".

To define the cognitive-theoretical assets of $\mathrm{K}$. Kłósak's concept, it is compared to contemporary means of philosophical reflection, among others on the example of Z. Augustynek's philosophical reflections on time and systemic ontology. Comparative analyses of this kind have proved that this specific practice in philosophy is based on particular sciences without limiting them to their empirical characteristics. It is aimed at subject studies of ontological nature and basc view of structures and processes. It is characterised by a certain ontological openness.

Kłósak's concept has much in common with the specific style of contemporary, first of all with ankering it, i.e. making it a subject of natural sciences. However, it goes much deeper and creates a coherent original theory in which ontological theses are neither simple conventions, nor contextual elements of the theory to be proved empirically, but ontological implications reductive in character. 
The conclusion points to the fact that Rev. Kłósak's chief attempt is to present the specificity of philosophy of nature and its autonomous character, with respect to natural sciences and metaphysics. Though it is built and constructed in the arising manner, philosophy of nature presented in this way is to explicate in a specifically ontological manner the material reality. 